\section{Inteligentne ornamenty. Forma i funkcja murali w przestrzeni urbanistycznej}

\section{Smart ornaments. The form and function of murals in urban space}

Abstrakt

Dziś sztuka to nie tylko eksponaty zamknięte w muzeach. Współczesny obraz miasta współkreują kolorowe murale i graffit. ją nasycone informacjami i znaczeniami, a dzięki egaltarnosci i wszechobecnosci przestrzeni publicznej - wszyscy ulega Murale, wykorzystujac architekture jak płótno, stanowia inteligentne, wspótczesne detale w przestrzeni. Poza funkcia estetyzujaç, przekazua informacie i znaczenia, wchodzac w relacie z mieszkańcami. Autorka bada różnorodne zespoty mural wybranych miast i podejmuje próbe kategoryzacji przyczyn ich powstawania.

Today art is not confined to exhibits enclosed in museums. The contemporary image of the city is co-created by colourful murals and graffiti. They are saturated with information and meaning, and thanks to their egalitarianism and ever-presence in public space-everybody becomes affected by them. They can bestow a persuasive function upon urban space, in which Aprmation intensely resonates. Murals, using architecture like a canvas, constitute smart, contemporary details in space. Apart from an aestheticising function, they convey information and meanings, entering into relationships with residents. The author investigated various complexes of murals of selected cities and made an attempt at categorising the causes of their creation.

Stowa kluczowe: przestrzeń publiczna, graffitit, mural, sztuka, tódż, Teheran, ekspresja, informacja, polityka miasta
Keywords: public space, graffiti, mural, art, tódź, Thran, expression, information, municipal policy

Pokonaliśmy ornament, osiagnęliśmy brak ornamentu powiedział Adolf Loos', twierdzạc,że piękno architektury w nowoczesności powinno objawiać się $w$ dokładności wykonania i szlachetności faktur. W wartościach, które wyrugować miały detale architektoniczne. W 1913 roku słowa te brzmiały niezwykle nowocześnie i dawały nadzieję, że po przesycie złotem i akspresją art nouveau przyjdą czasy czystej bezpretensjonalnosci. Nie wiedzia jednak, że, wraz z czystością formy, nadejdą miasta zło zone z płaszczyzn, powierzchni i faktur, nie zawsze wy konanych dokładnie i ze szlachetnych materiałów. Dzi zabudowa powstaje szybciej niż kiedykolwiek, a społeczenstwo zywiej partycypuje w kreowaniu charakter miasta. Dzisiaj na ulice wychodzi także sztuka, a współczesny obraz miasta współkreują kolorowe murale i niebanalane graffiti. Ich liczebność nieraz wynika z polityk przestrzennej miasta.

Malatura to znana od wieków część ornamentyki architektonicznej, wykonana farbami na ścianie, drewnie lub szkle. W architekturze i sztuce tradycyjnej znamy ia
We have conquered ornament, we have won through to lack of ornamentation-said Adolf Loos', claiming that he beaty of achitecture in modernity should manifs itself in the precision of workmanship and nobility of exture In values that architectural details were meant expunge In 1913 these words sounded remarkably modern and gave hope that after an excess of gold and expression of the art nouveau, times of pure unpretentousness would arrive. However, he did not know the long with a purity of form, cities composed of planes, surfaces and textures would come, not necessarily always built with precision and out of noble materials. society participates in the creation of the character of the city in a more lively manner. Today art has taken to the streets as well, and the contemporary image of the city is co-created by colourful murals and sophisticated graffiti. Their numerousness is sometimes the result of a city's spatial policy.

Wall paintings (malatura in Polish) are a part of architectural ornamentation that has been known for Today buildings are being built faster than ever, and

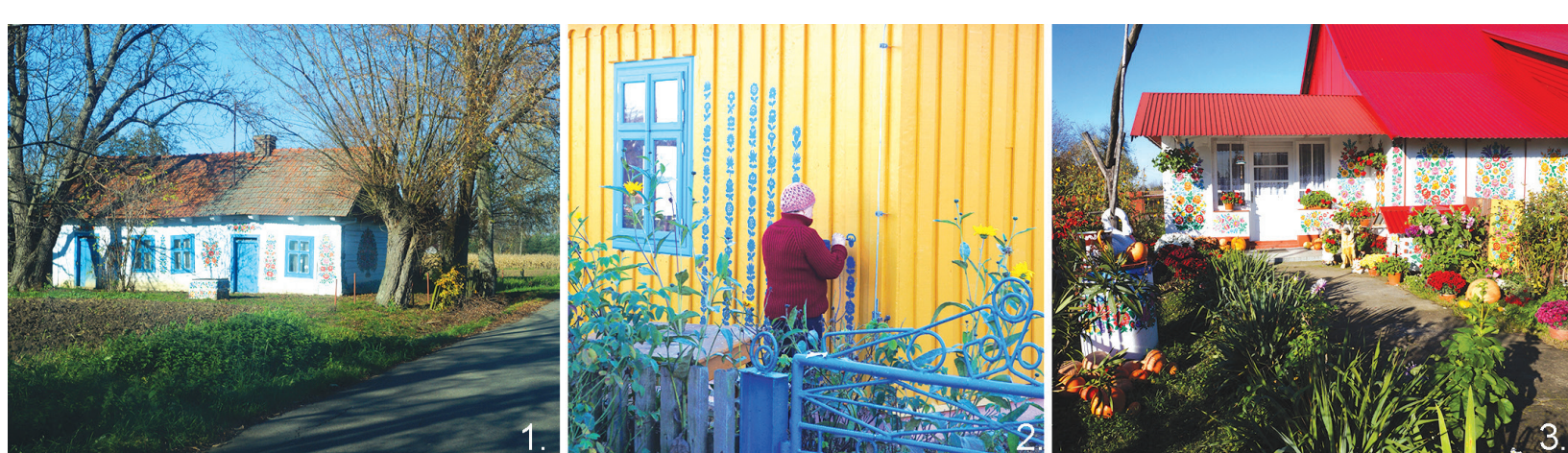

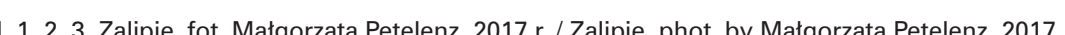

przede wszystkim jako polichromię czy freski. Dopóki możliwości materiałowe nie pozwoliły na tworzenie malowide zewnetznych odponch na warne ferycze byla to sztura zdobipca przewaine wnetza.

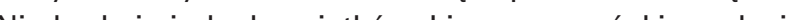

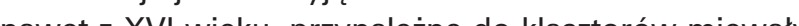
polic z XVI wieku, przynaleźne do klasztorow miewaly

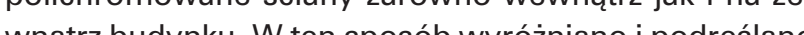
w ja budy ku. W ten sposób wyróziano i podreslano Wię kow cs s swą̧tyni pośrodku kompleksu monastyru. Wiejka cha supa pomalowana z zow watrz na blekthy kolor mogła sugerować, że mieszka w niej panna gotowa do zamąż́ójścia. Był to prosty i jednoznaczny sposób na przekazanie informacji mieszkańcom, pozostający jednocześnie w duchu tradycji bielenia i zdobienia ścian. Do dzisiaj można zauważyc, że $\mathrm{m}$. in. w miejscowości Zalipie regularnie odmalowywane są wiejskie chałupy ludowymi, kwiatowymi wzorami. Działania te, choc obecnie pozbawione znamion użyteczności, nadają wsi niezwykły i malowniczy charakter. Choć ten proces wydaje się być raczej reliktem przeszłości to malowan wieś, dzięki tradycji, stanowi atrakcję turystyczna.

Mieszkając w mieście codziennie poruszamy sie przez przeptywające, przenikajace sie liczne przestrzenie publiczne. Mijamy sztuke uliczna billboardy, murale, które tworza malowane miasta. Każde z nich zawiera informacje, a każdy przechodzień ulega ich wptywowi. Autorka w dalszej czści atyku bada zespoly murali wybrawych miast i podejmuje próbe kategoryzai prayczy uje próbe kategoryzacii przyczyn ich powstawania.

GENEZA

Potrzeba pokrywania ścian malowidłami trwa w człowieku od początku narodzin cywilizacji. Jedne z pierwszych szkolnych lekcji z historii sztuki ${ }^{4}$ dotycza malowide ściennych $w$ grotach $w$ Lascaux czy Altamirze. Rysunki zwierzat i ludzi ryto w skale, a kontur wypetniano farba Hipotez, określajacych cel ich wykonywania jest wiele, jednak bezsporna, z punktu widzenia dzisiejszego badania, jest ich wartość artystyczna oraz fakt, że stanowią podwalinę sztuki znanej dziś.

Jednymi z najsłynniejszych przykładów malarstwa ściennego w kulturze europejskiej są freski włoskich artystów renesansu. Malowidła Giotta z XIIIw. w bazylice św. centuries, painted on walls, wood or glass. In archiecture and traditional art we are primarily familiar with it as polychromes or frescoes. Up until materia capabilities allowed making external paintings resistant to atmospheric conditions ${ }^{2}$, it had been an art primarily confined to interior decoration. However, there is no shortage of exceptions. Numerous Romanian Orthodox churches, even from the sixteenth century, belonging to monasteries, sometimes featured polychromes on walls both inside and outside the building. The exceptionality of the temple amid scored in this manner.

A village hus manner. A village hut with its external walls painted blue migh reas suggested that it was inhabited by a maiden mand that sime the tradition of painting walls in white and decorating them. Even toda we can in the locality of Zalipie, village huts are being regularly painted in folk floral patterns. These measures although currently bereft of utilitarian characteristics, give the village an extraordinary and picturesque character. Even though the process appears to be a relic of the past, the painted village, thanks to tradition, constitutes a tourist attraction.

When living in the city we move through numerous lowing, mutually intersecting public spaces every day. We pass by street art, billboards and murals which form painted cities. Each contains informathon, and every passerby is subjected to their influence. In the following part of the article, the author investigates complexes of murals of selected cities of their creation.

GENESIS

The need to cover walls with paintings has resided within man since the beginning of the birth of civilisation. One of the first school lessons on the history of the arts ${ }^{4}$ are on the subject of cave wall paintings in Lascaux or Altamira. Drawings of animals and humans were carved into the rock and the contour was filled in with paint. Hypotheses concerning the aim tive of today's studies, their artistic value and the fact 
Franciszka w Asyżu przedstawiają paralelizm historii św. Franciszka i scen z $z$ biblia pauperum, przybliżająca obrazy z Nowego Testamentu wiernym, którzy nie potrafili czytać. Jednocześni nadawały świątyni charakter dzieła sztuki i wprowadzały nastrój radosnego skupienia. Freski w Kaplicy Sykstyńskiej autorstwa m.in. Sandro Boticellego, Pietra Perugina i Michała Anioła również miały wzbudzić uznanie obserwatorów Kaplica przeznaczona była na wyjatkowe obsecystós koście zatem przeznyczenie myątkowe

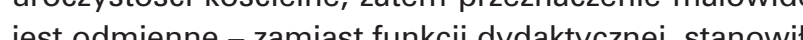
jest odmien - za Obrazy Utzymane w dramatycznym, mon inwestorów. Obrazy utrzymane w dramatycznym, monumentalnym
charakterze wprowadzają nastrój trwogi i pokory wobec charakterze wprowadza
boskiego majestatu.

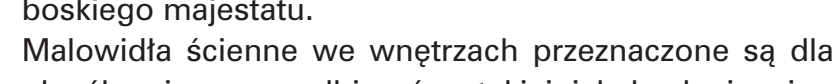
okreslonej grupy odbiorcow, takiej jak kapłani, wier$\mathrm{ni}$, mieszkancy, dwôr krolewski etc. Z kolei malowidła scienne znajdujące sie w przestreni publicznej rezonuja u zdecydowanie większej i zrozznicowanej grupy odbior ców, a ich powstawanie często powodowane jest odmiennymi ideam

\section{MURAL CZY GRAFFITI?}

Współczesna, miejska sztuka malowideł ściennych widoczna jest $\mathrm{W}$ przestrzeni publicznej pod wieloma postaciami. Graffiti, które, jako tzw. sztuka uliczna ${ }^{5}$, stanow wypowiedź autorów -writerów ${ }^{6}$ - spoza artystycznego establishmentu, którzy nieraz działają poza prawem. Pozostają anonimowi, a w przestrzeni pozostawiają wypowiedzi na tyle krótkie, by nie zostać zatrzymanym przez służby porządkowe za wandalizm.

Tożsamość Banksy'ego - jednego z najsłynniejszych wciąz aktywnych writerów graffiti - jest znana jedynie nielicznym. Zachowuje anonimowość nawet udzielaja wywiadów czy realizujac film dokumentalny o swoje twórczości? Mitość jest w koszu to nowy tytut dzieta Banksy'ego, którego papierowa, oprawion w rame Banky'ego, kitosc jest wa koszu to nowy ty w dzam trafita na a kcje domu aukcyjnego Sotheby's w paździc trafla za arce wo do likn 2018 . Dzielo zosta spéc Dizew

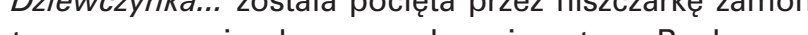
towana w ramie obrazu na zlecenie autora. Banksy, nawet gdy trafia na salony i wstępuje w szeregi panteonu uznanych artystow, pozostaje w opozycji. Komercjalizacja, wielkie korporacje, wojna, terroryzm etc. to tematy jego prac, ktorym komentuje przywary wspótczesnośc Pozostaje wierny kulturze street artu, która charakteryzuje się nieuchwytnością, brakiem reguł $i$ często sprzeciwem wobec systemu. To sztuka buntu i prowokacjl. Przechadzając się ulicami miast, najczęściej spotyka się graffiti o niskiej wartości artystycznej, jednak postac Banksy'ego ukazuje, ze jako forma twórczości uliczne jest zróżnicowana jak każda inna dziedzina działalności człowieka. Graffiti jednak kojarzy się z działalnością nielegalną i wulgarną, stojącą w sprzeczności z zaplanowa- that they form the foundation of the arts as we know them, is incontestable.

One of the oldest examples of wall paintings in European culture are the frescoes of Renaissance artists. Giotto's paintings from the thirteenth century at the Basilica of St. Francis in Assisi, depict the parallelism of the history of St. Francis and scenes from the life of Christ. They constituted a sort of biblia pauperum, making images from the New Testament familiar to bestowed whon the temple the Simultaneously, they of art and introduce an centration. Frescoes in the Sistine Chapel by Sandro Boticelli, Pietro Perugino and Michelangelo were also meant to elicit the acknowledgement of onlookers. The chapel was meant for exceptional church ceremonies, and thus the purpose of the paintings was different-instead of a didactic function, they constituted representative proof of the power of the artists and their clients. The paintings, maintained in a dramatic monumental character, introduce an atmosphere of fear and humility before the majesty of God.

Wall paintings in interiors are meant for a specific audience, such as priests, the faithful, residents, a roya court, etc. In turn, wall paintings located within public space resonate with a much greater and diverse audience and their creation is often brought about by different ideas.

\section{MURAL OR GRAFFITI?}

The contemporary urban art of wall painting is visible in public space in different forms. Graffiti, a authors-writers ${ }^{6}$ - from outside of the artistic establishment, who often act against the law. They remain lishment, who often act against the law. They remain anonymous, and leave messages in space that are
short enough to make them avoid being arrested by law enforcement for vandalism.

The identity of Banksy-one of the most famous still-active graffiti writers-is known to but a few. He maintains anonymity even while giving interviews or when making a documentary on his work?. Shredded Girl with Balloon is the new title of Banksy's work whose paper, framed version, previously known as Girl with Balloon, was auctioned at the Sotheby's auc tion house in October 2018. The work, sold for 1,024 million pounds ${ }^{8}$, at the final sound of the auctioneer's hammer, was shredded by a mechanism that had been fitted into the frame on the orders of the author. Banksy, even when hitting the showrooms and enterremains ins of the pantheon of acclaimed artists, corporations, war, terrorism, etc, are the subjects of his works, with which he comments on the flaws of contemporaneity. He remains faithful to street art culture, which is characterised by fleetingness, a ck rules and often an opposition to the system. It is an art of rebellion and provocation.

When strolling along city streets, we most often encounter graffiti of low artistic value, however, Banksy's character has shown that, as a form of street art, it is as diverse as any other field of human activity. How-
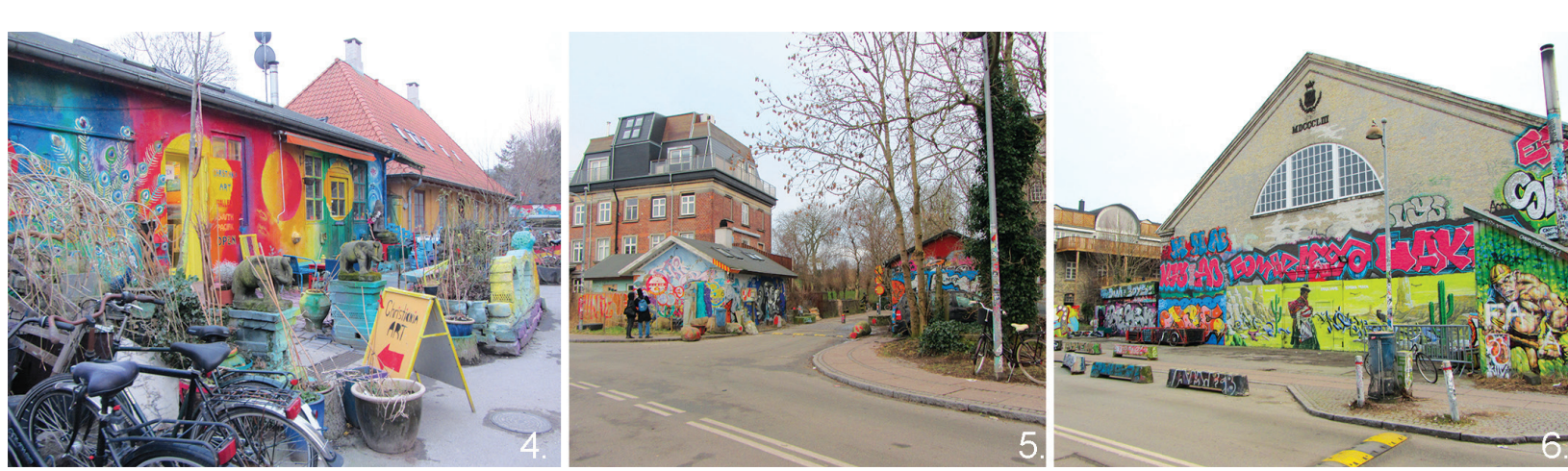

4. 4, 5, 6. Christiania, Kopenhaga, fot. Małgorzata Petelenz, 2018 r. / Christiania, Copenhagen, phot. by Małgorzata Petelenz, 2018

nym, inteligentnym rozwojem miasta. Bywa jednak nieodłacznym detalem we współczesnym obrazie miasta który może zachwycać lub szpecić.

Christiania to samostanowiąca się dzielnica Kopenhag znana z hipisowskiego i niezależnego charakteru. Teren dzielnicy, jak i drogi prowadzące do jej bram, udekorowane są barwnymi malowidłami ściennymi wyznaczającymi granice obszaru. Są przykładem możliwości wspótistnienia i przenikania się murali i graffiti. Maja zróżnicowaną wartość estetyczną oraz szkicują granic dominacji danej społeczności w przestrzeni miasta. Sa zarówno ekspresyjne jak i informatywne.

Niekontrolowana sztuka ulicy charakteryzuje się egalitaryzmem, gdyż tu twórcą może być każdy. Murale, choc to nazwa okreslająca jedynie formę dzieła, są rodzajem sformalizowanej interwencji w przestrzeni miejskiej, która może być zaprojektowana w większej skali. Uprawnione organy miast planują powstanie i rozmieszczenie murali, zapraszając wykwalifikowanych artystów. Nieraz struktura miasta sama stwarza pole do organizowania murali, które - jako element właściwej strategii - moga stać sie narzedziem poprawy jakości istniejącej już przestrzeni publicznej.

Eduardo Kobra jest jednym z nasłynniejszych twórców murali na świecie. Jest obecnie (wraz z zespotem) au-

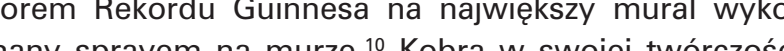
poto pow corza $z$ charaktorystycznym, geometrycznym wzoren. Jest 2016 zokul Mstzow Olmpiskich w Rio de Janiro w 2016 roku, reprezentującego pięc grup etnicznych wszystkic kontynentów. Jego osiągnięcia ukazują skalę popularnosci murali w popkulturze. Kobra zapraszany jest do wspołpracy z miastami na całym świecie. Działa prze de wszystkim w Południowej i Północnej Ameryce, ale bywa gościem także w Europie - np. jest twórcą barwnego muralu na scianie budynku przy ul. Sienkiewicza 18 w Łodzi, przedstawiającego Artura Rubinsteina. ${ }^{11}$ Twórczość muralistów przestała stanowić margines współczesnej sztuki.

W Polsce pojęcie muralu często kojarzy się w okresem PRL-u, kiedy to zyskał popularność, jako forma reklamy ever, graffiti is associated with illegal and vulgar ac and smet havernain in opposilion with the planned sometimes an inseparable detail in the contemporary image of the city that can either delight or deface. Christiania is a self-sufficient district of Copenhage known for its hippie-like and independent character. The district itself, as well as the streets that lead to its gates, are decorated with colourful wall paintings delineating the border of the area. They are an example of the possibility of coexistence and blending of murals and graffitit. They are of differing aesthetic value and outline the dominance of a given community within the space of the city. They are as expressive as they are informative.

Uncontrolled street art is characterised by egalitarianism, as here anybody can be an artist. Murals, although it is a name that describes merely the form of work', are a type of formalised intervention with The appropriately empowered municipar orgens the creation and positioning of murals, inviting qualified artists. Oftentimes the structure of the city provides a field for the organisation of murals all by itself as they-as an element of an appropriate strategycan become a tool of the improvement of the quality of an already existing public space.

Eduardo Kobra is one of the most famous mural artists in the world. He is currently (along with his team) a Guinness World Record-holder for the larges spray-painted wall mural' 0 . In his work, Kobra repeats the scheme of the portrait or a silhouette combined with a distinct, geometric pattern. He is the author of the famous mural $A / /$ are One made on the occasion of the Olympic Games hosted in Rio de Janeiro in 2016, representing five ethnic groups from all of the f the popurity. His achievements show the scale invited to coperate with cities all around the world is also opera in South and North America but is sometimes also present in Europe $-\mathrm{g}$. he is the a 18 Sienkiewicza Street in tódź, depicting Artur Ru binstein ${ }^{11}$. The work of muralists has ceased to reside on the margins of contemporary art.

In Poland the notion of the mural is often associated with the period of the People's Republic of Poland 
przedsiębiorstw $\mathrm{i}$ instytucji. Wciąż można spotkać zachowane $\mathrm{w}$ przestrzeni publicznej murale reklamujace Pewex (Gdańsk) lub banku PKO BP (Gdynia), które dzis stanowią jedynie pamiątkę minionej epoki.

Murale moga jednak pełnić rozmaite funkcje. Podobnie jak w PRLu, dziś również można spotkać tymczasowe murale reklamujace sklepy (np. reklama sklepu odzieżowego Medicine na ścianie budynku przy ul. Karmelckiej 28, w Krakowie, we wrześniu 2018r. czy festiwale, mura prok korzystuje krakowske symboje jak np. smok wawy wygolębie, barkę na W gołębie, barkę na Wisle, czy Kośció Mariacki by pow
kierowców nadjeżdzających do centrum z południa.

\section{UTILITAS}

Przestrzeń publiczna, w której informacje intensywnie rezonuja, stwarza możliwość tworzenia sztuki jako wypowiedzi, czy manifestu o rozległym zasięgu, co czyni ja cennym narzędziem w społeczeństwie informacyjnym. Amerykanski multimilioner Rockefeller w 1933 roku zamówit u Diego Rivery mural do Rockefeller Center w Nowym Jorku - Man at the Crossroads. Dzieło powstało, będąc jednocześnie manifestem politycznym artysty - nakazano jednak je zniszczyc, gdy Rockefeller dopatrzył się w dziele podobizny Lenina. ${ }^{12}$ Rivera jes przykładem artysty zangazowanego politycznie. Wielokrotnie twierdzit, że murale są jedną z najdoskonalszych technik artystycznych, ze względu na egalitarność przekazu i szerokie grono odbiorców.

Konflikt w Irlandii Północnej, trwający do lat '60tych XX wieku znalazł odzwierciedlenie także $w$ ulicznej, symbolicznej wojnie o wpływy w przestrzeni publicznej. Konflikt nacjonalistów i republikanów - tzw. The Troubles - zapoczatkowat i spopularyzowat irlandzka tradycie murali jako wypowiedzi i kronik politycznych. Od lat sie demdzictych $X X$ wieku odnotowano ich ponad dwa tysiace. Murale na ścienach domów Belfastu, Derry i in-

nych miast Irlandii Północnej, okrzyknięte jednymi z naj-

when it became popular as a form of advertisement (G bank (Gdynia) in public space, which currently const列

However, murals can fulfil various functions. Similarly as during the People's Republic of Poland, we can still encounter murals advertising stores (e.g. an wall of a building at 28 Karmelick Street in $\mathrm{K}$ the in September 2018) or festivals, murals promoting a city or a geographic region, e.g. the mural neaby Konopnickiej Street in Krakow, which utilises Krakow's symbols, such as the Wawel dragon, pigeons, a barge on the Vistula or St Mary's Church to welcome drivers entering the city centre from the south.

\section{UTILITAS}

Public space, in which information intensely resonates, provides opportunities for creating art as a message or manifesto with a broad reach, which makes it a valuable tool in information society.

The American multi-millionaire Rockefeller commissioned Diego Rivera to paint a mural for the Rockefeller Center in New York in 1933-called Man at the crossroads. The work was made while simultaneously being the artist's political manifesto-however, it was ordered to be destroyed when Rockefeller recognised Lenin's face in the work'12. Rivera is an example of a poltically involved artist. He claimed fect artistic techniques due to the egalitarian naturf their message and broad audience.ch .

1960's found its reflectiond which lasted up to influence in public space waged in the streets. The conflict between nationalists and republicans- The The Troubles-initiated and popularised the Irish tradition of making murals as a form of political expression and chronicling events. Since the 1970 's, over two thousand of such murals have been recorded. Murals on the walls of houses in Belfast, Derry and other cities of Northern Ireland, proclaimed some of

II. 7. Belfast, $h$ tttps://en.wikipedia.org/wiki/Murals in_Northern_Ireland\#/media/File:An_gorta_Mor.jpg [dostepp: 15.10.2018] / Belfast, $h$ ttps:://
en.wikipedia.org/wiki/Murals_in_Northern_Ireland\#\#/media/File:An_gorta_Mor.jpg [retrieved on: 15.10.2018] II. 8. Man at the Crossroads, https://www.diegorivera.org/man-at-the-crossr
www.diegorivera.org/man-at-the-crossroads.jpp [retrieved on: 14.10.2018]
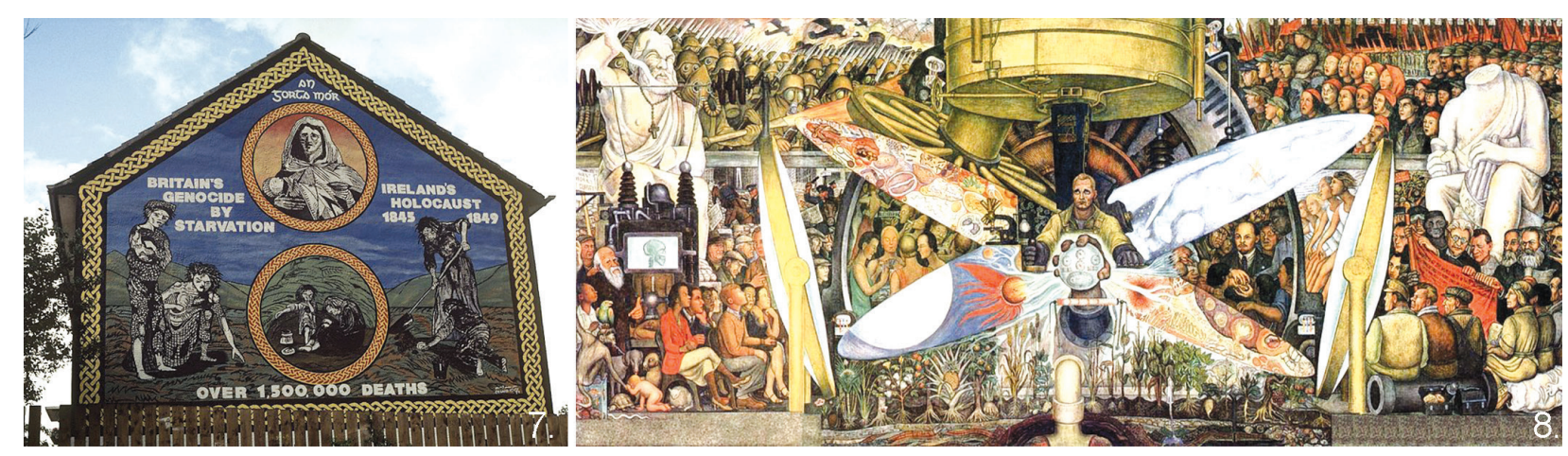

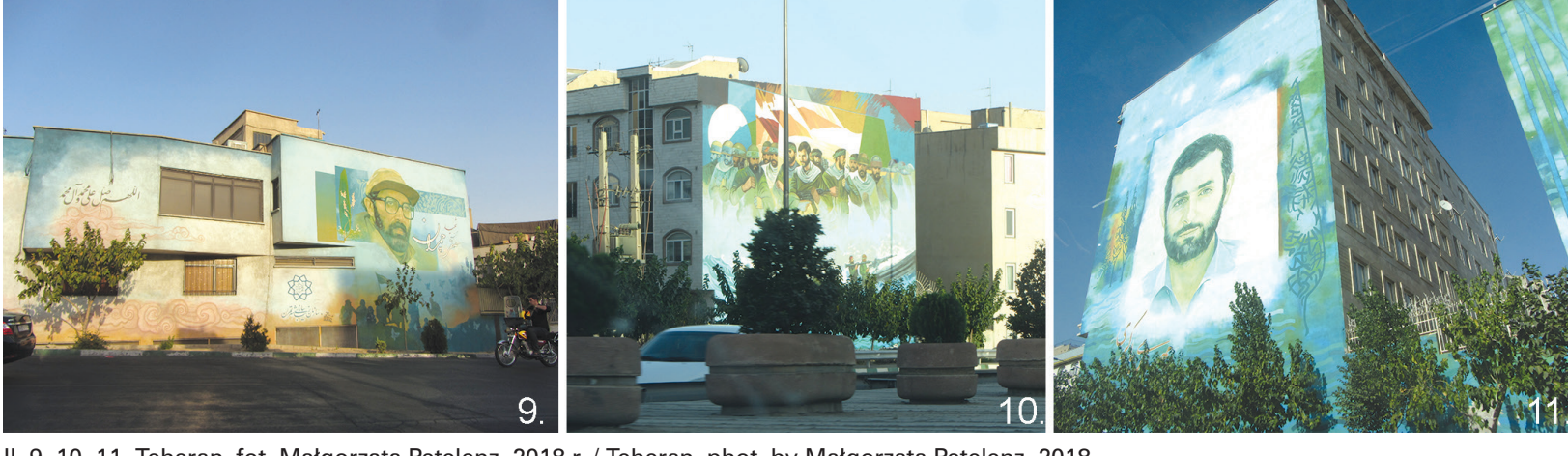

bardziej politycznych murali w Europie, są już wpisane $w$ kulture popularna tak powszechnie, że dotyczące ich nej Wikipedii' ${ }^{13}$

Teheran, stolica i miasto północnego Iranu, również obfituje w murale o dużej skali $i$ liczebności. Mityczna bitwa pod Karbala, męczeństwo Imama Husseina, Irańska Rewolucja $z$ lat osiemdziesiątych czy wojna z Irakiem to wydarzenia z historii Iranu, które przenikaja się w społecznej świadomości Irańczyków pomimo, iż dzie je ponad tysiąc lat. Miasto można porównać $z$ wielkim cmentarzem ze względu na liczbę murali przedstawiających podobizny shahidów - zmarłych żołnierzy m.in. w wojnie z Irakiem (tzw. Holy Defense). ${ }^{14}$ Męczennicy przedstawieni są jako monumentalne portrety, $z$ atrybutami gloryfikującymi ich dokonania, jako charakteryzujahasło stanowi niezależną stronę na portalu anglojęzycz- the most political murals in Europe, have become engrained into popular culture so much they have their own independent entry on the English-language version of Wikipedia ${ }^{13}$.

Tehran, the state capital and a city in northern Iran, is numerous. The mythical battle of Karbala, the mar-

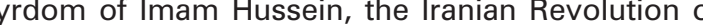
(ye 1980 's or the war with Iraq are events from Iran's iscory Irentans despite being over a thousand years apart. The cily can be compared to an enormous cemetery the number of murals depicting shacald monumely Dence) "The mary wis are depicted on achievem portsaiss whith atributes glorifying their also replete with murals that are both large-scale and

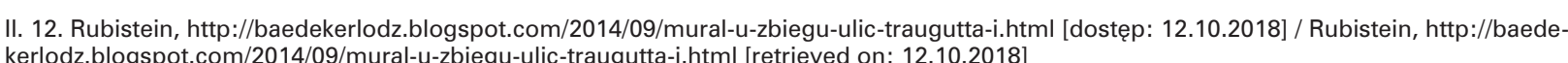

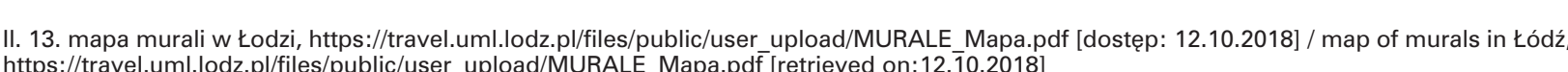

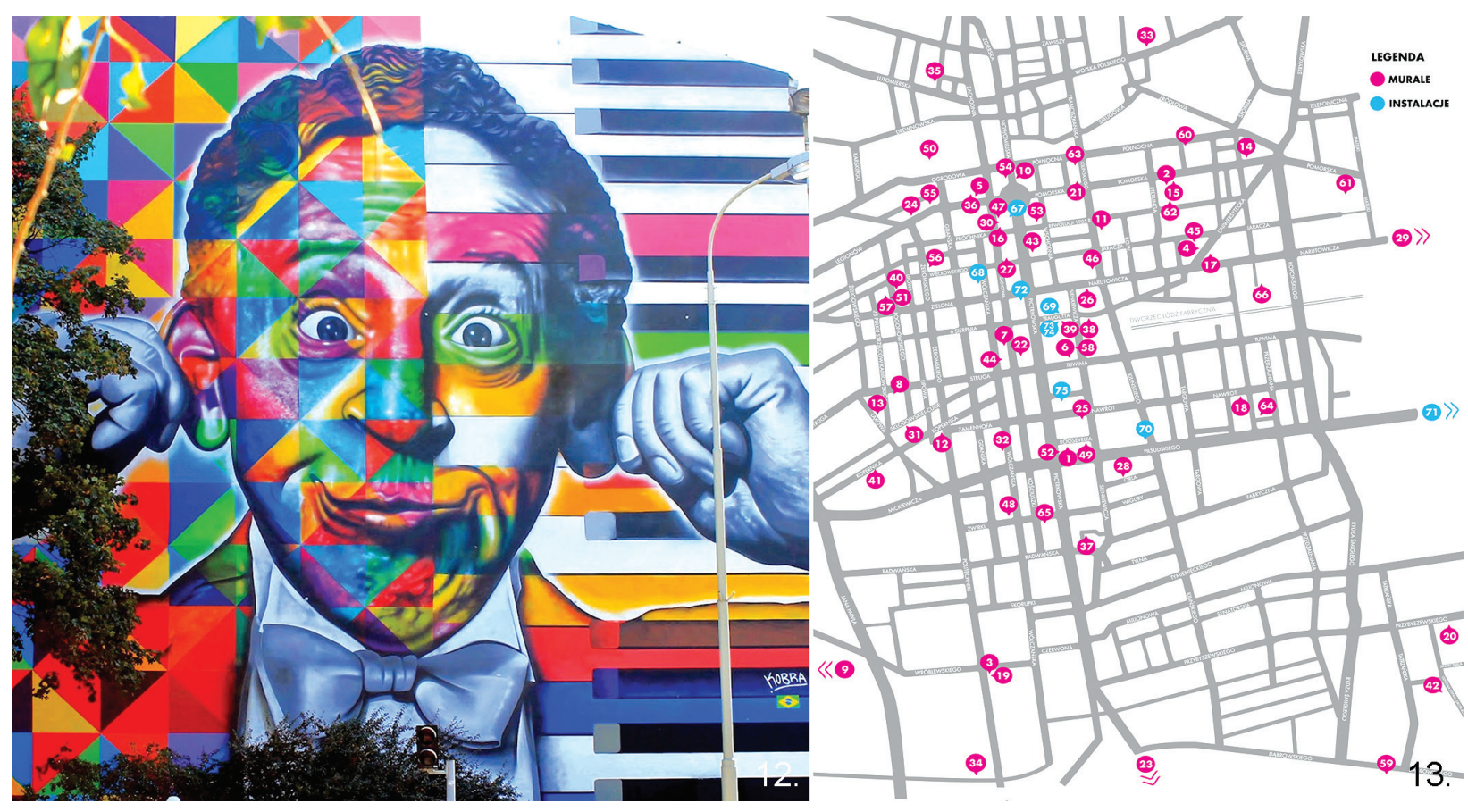


ce się spełnieniem i chwałą (np. postaci ukazywane są rzyszą im przedstawienia białych gołębi - symbol zbawionej duszy, czy czerwone kwiaty - symbol męczeństwa). Niejednokrotnie na muralach znajdują się również podobizny przywódców religijnych, co konstytuuje ich zgodność z dominującym dyskursem politycznym.

Regulacje dotyczace wysokości zabudowy w Teheranie praktycznie nie istnieja15, dlatego też w lini pierzei można zauważyć sa isiadujace ze soba budyni radykozróżniąe sie od siebie wysokościa co powoduje liczebnó́ć pustych ścian szczytowych. Murale, któne mogty nosc pusych scian szcy owych, co powa koje liczeb-

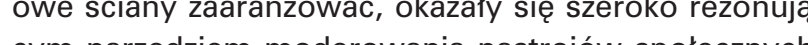
cym narzédziem moderowania nastrojow spolecznych. Mreszkancy Teh mod rowania na codzen dzialanie dziesiątek propagandowych malowideł jednostajnych zarówno w treści, jak i spójnych w stylistyce. Sklania to do wyciagnięcia wnioskow, iz to nie wartośc estetyczna formy murali jest istotna $w$ polityce Teheranu, ale monotonia i powtarzalnośc treści upolitycznionych, a zatem ich użyteczność.

\section{VENUSTAS}

Podczas II Wojny Światowej dużą część mieszkańców Łodzi stanowili Niemcy, dlatego też miasto nie uległo wielkim zniszczeniom. Ze względu na jej robotniczy charakter, Armia Czerwona również oszczędziła tę miejsk strukturę. Po wojnie jednak Łódź zaczęła rozwijać się zby intensywnie. Układ komunikacyjny okazał się niewystarczający przy gwałtownie rosnącej liczbie mieszkańców i dodawanych kolejnych obszarach peryferyjnych do granic miasta. Restrukturyacja wymagała niejednokrotnie wyburzania całych pierzei, a także likwidowania kamienic narożnych (np. podczas budowy Trasy P-P i Trasy W-Z17), co spowodowało powstanie licznych ścian szczytowych w centrum todzi. Owa wyszczerbiona" struktu-

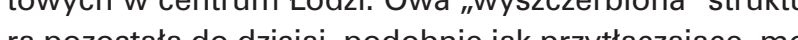
numentalne, puste ściany.

Galeria fundacji Urban Forms wskazuje na mapie murali Łodzi ponad sześćdziesiąt lokalizacji, w których można zobaczyć malowidła ścienne. ${ }^{18} \mathrm{~W}$ sumie na terenie miasta można znaleźć ich ponad 70 . Nadają Łodzi nową

glory (e.g. their figures are shown on a bright blue and are accompanied by images of white pigeonsthe symbol of a saved soul, or red flowers-a symbo of martyrdom). Oftentimes, murals also depict the images of religious leaders, which constitutes their concordance with the dominant political discourse. Regulations concerning the height of buildings in Tehran are practically non-existent's, which is why we can the line of the same frontage, which leads to a gret number of empty gable walls. Murals thats to a grea these walls have turned out to be a broadly resonating tool for moderating public attitudes. Tehran's residents' are exposed to the influence of tens of propaganda paintings that are monotonous in terms of content and coherent in their style. This leads to a conclusion that it is not the aesthetic value of murals that is essential in Tehran's politics, but the monotony and repetitiveness of political messages and their usefulness.

\section{VENUSTAS}

During the Second World War a large portion of Łódż's residents were Germans, which is why the city was not damaged too much. Due to its workingclass character, the Red Army also spared this urban structure. However, after the war, Łódź started to develop with an excessive intensity. The circulation layrapidly growing number of residents and the addition of successive peripheral areas to the city's limits. Its restructuring often required the demolition of entire frontages, as well as dismantling corner townhouses (e.g. during the construction of Route P-P and Route W- $-Z^{17}$, which caused the emergence of numerous gable walls in the centre of Łódź. This "jagged" structure has remained to this day, similarly to the overbearing, monumental, empty walls.

The gallery of the Urban Forms foundation shows over sixty sites where we can see wall paintings on tódź's murals map ${ }^{18}$. We can find over 70 of them in total in the city. They give Łodż a new identitytoday it is no longer only a post-industrial city with a turbulent past, but also a living gallery of murals, known around the entire world. Street art in Łódz is an example of a policy which turns the city's dis-
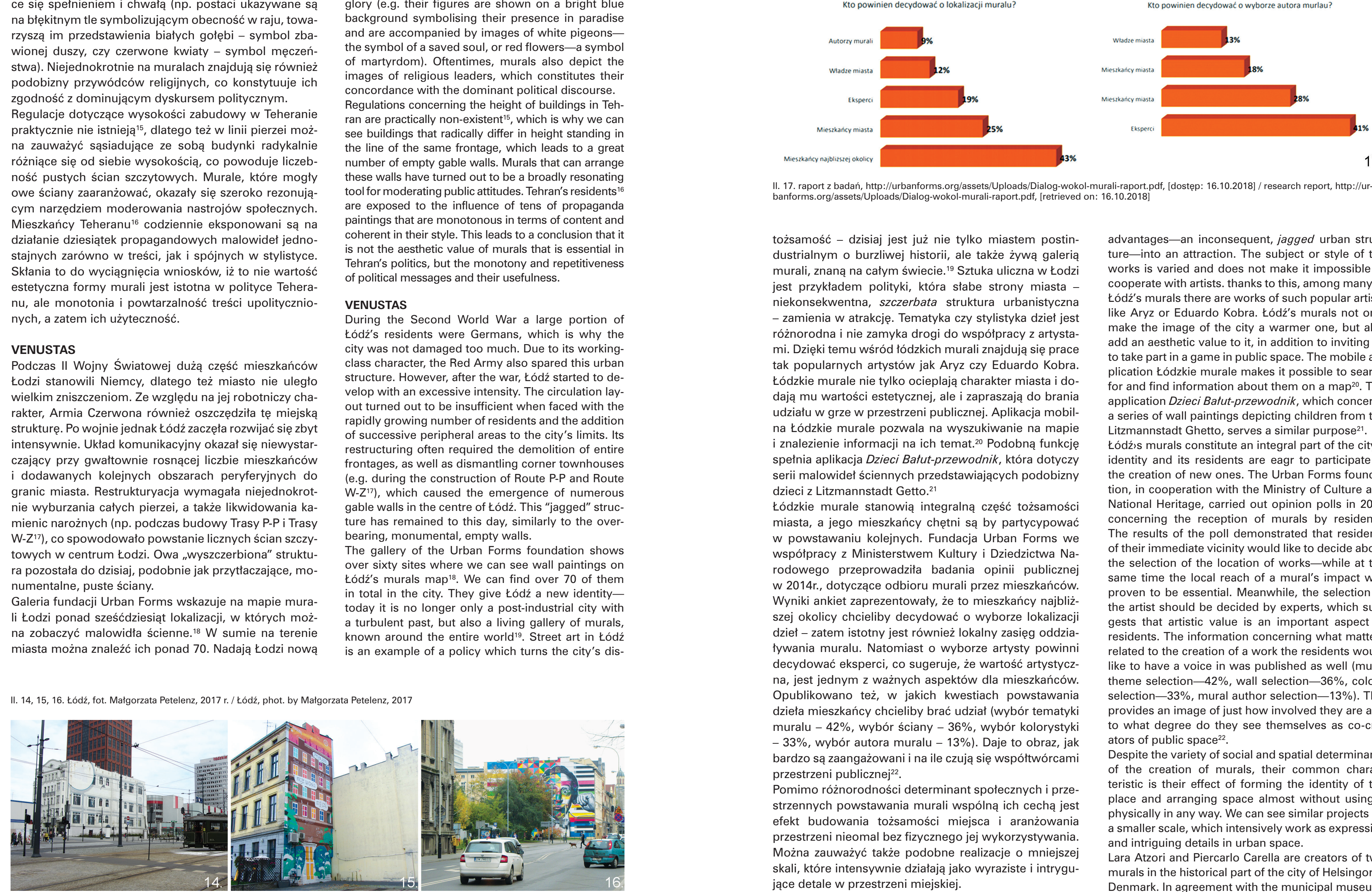

II. 17. raport z badań, http:///urbanforms.org/assets/Uploads/Dialog-wokol-murali-raport.pdf, [dostẹp: 16.10.2018] / research report, http://ur-
banforms.org/assets/Uploads/Dialog-wokol-murali-raportt.pdf, [retrieved on: 16.10.2018]

tożsamość - dzisiaj jest już nie tylko miastem postindustrialnym o burzliwej historii, ale także żywą galeria

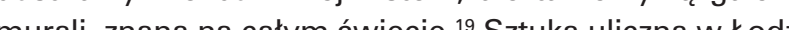
ply

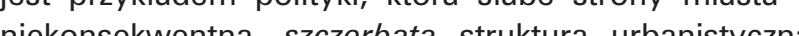
zamienia watakje. Tematyk czy sylistya dze jest - ż́n oźnorodna i nie zamyka drogi do wspótpracy z artystami. Dzięki temu wśrod lodzkich murali znajdują się prace tak popularnych artystow jak Aryz czy Eduardo Kobra. Lódzkie murale nie tylko ocieplają charakter miasta i dodają mu wartości estetycznej, ale i zapraszają do brania udziału w grze w przestrzeni publicznej. Aplikacja mobina Łódzkie murale pozwala na wyszukiwanie na mapie i znalezienie informacji na ich temat. ${ }^{20}$ Podobną funkcje spełnia aplikacja Dzieci Bałut-przewodnik, która dotyczy serii malowideł sciennych przedstawiających podobizny dzieci z Litzmannstadt Getto. ${ }^{2}$

Łódzkie murale stanowią integralną część tożsamośc miasta, a jego mieszkańcy chętni są by partycypować w powstawaniu kolejnych. Fundacja Urban Forms we współpracy z Ministerstwem Kultury i Dziedzictwa Narodowego przeprowadziła badania opinii publiczne w 2014r. dotyczące odbioru murali przez mieszká́ć Wyniki a Wy dziel - zacy chcief iby decydowac o wyboze lokelzaci decydowac elsperci, co sugevije, ze wartosc artystycz-

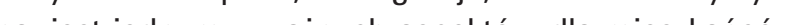
na, jest jednym $z$ ważnych aspektów da mieszkanców. Opublkowano tez, w jakich kwestach powstawania dzieła mieszkancy chcieliby brac udzial (wybór tematy muralu - 42\%, wybor ściany - $36 \%$, wybor kolorysty $-33 \%$, wybor autora muralu $-13 \%$ ). Daje to obraz, jak bardzo są zaangazzowani i na ile czują się wspóttwórcam przestrzeni publicznej

Pomimo różnorodności determinant społecznych i przestrzennych powstawania murali wspólną ich cechą jest efekt budowania tożsamości miejsca i aranżowania przestrzeni nieomal bez fizycznego jej wykorzystywania. Moznna zauwazyc także podobne realizacje o mniejsze skali, które intensywnie działają jako wyraziste i intrygujące detale $\mathrm{w}$ przestrzeni miejskiej. advantages-an inconsequent, jagged urban structherks is an attrion. The subject or style of the cooperate with artists. thanks to this, among many of kódz's murals there are works of such popular artists like Aryz or Eduardo Kobra. tódz's murals not only make the image of the city a warmer one, but also add an aesthetic value to it in addition to inviting us to take part in a game in public space. The mobile ap plication tódzkie murale makes it possible to search for and find information about them on a map ${ }^{20}$. The application Dzieci Bałut-przewodnik, which concerns a series of wall paintings depicting children from the Litzmannstadt Ghetto, serves a similar purpose ${ }^{21}$. Łódźıs murals constitute an integral part of the city's identity and its residents are eagr to participate in the creation of new ones. The Urban Forms foundation, in cooperation with the Ministry of Culture and National Heritage, carried out opinion polls in 2014 concerning the reception of murals by residents. The results of the poll demonstrated that residents of their immediate vicinity would like to decide about the selection of the location of works-while at the same time the local reach of a mural's impact was proven to be essential. Meanwhile, the selection of the artist should be decided by experts, which sug gests that artistic value is an important aspect to residents. The information concerning what matters elated to the creation of a work the residents would like to have a voice in was published as well (mural theme selection-42\%, wall selection- $36 \%$, colou selection- $33 \%$, mural author selection-13\%). This provides an image or just how sinvolved hey are and ators of public spacter.

Despite the variety of social and spatial determinants of the creation of murals, their common characteristic is their effect of forming the identity of the place and arranging of for almost without using it physically in any way. We can see similar projects on a smaller scale, which intensively work as expressive and intriguing details in urban space.

Lara Atzori and Piercarlo Carella are creators of two murals in the historical part of the city of Helsingor in Denmark. In agreement with the municipal museum 


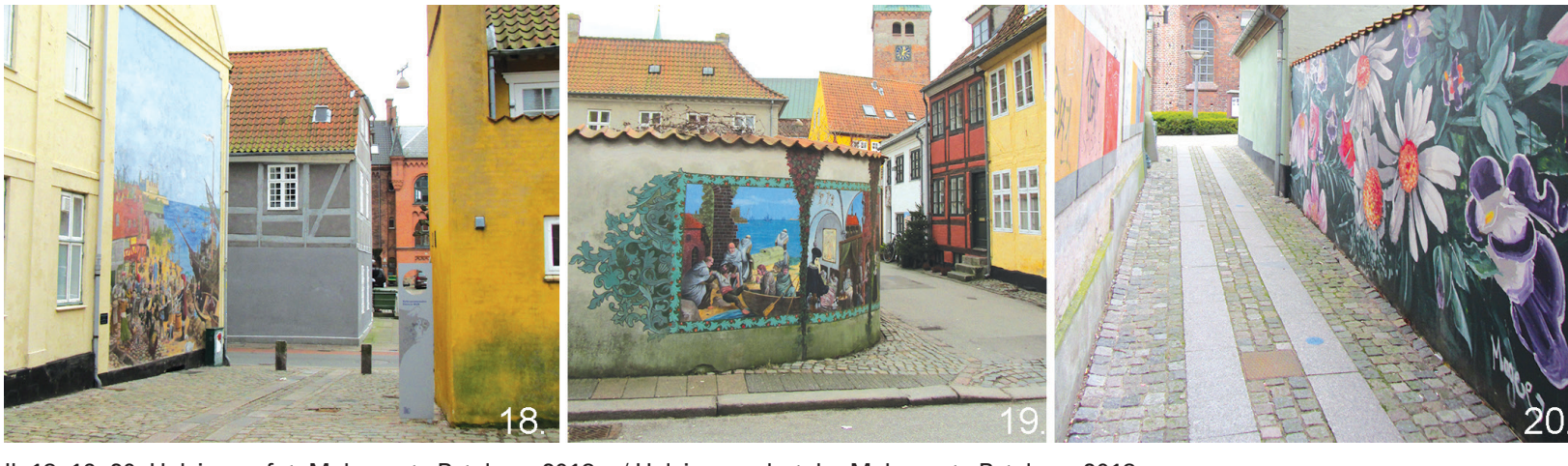

II. 18, 19, 20. Helsingor, fot. Małgorzata Petelenz, $2018 \mathrm{r}$./Helsingor, phot. by Małgorzata Petelenz, 2018

Lara Atzori i Piercarlo Carella to twórcy dwóch murali z zabytkowej częs zumieniu z muzeum miejskm wykonali dwa malowidta

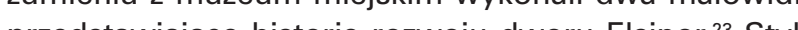

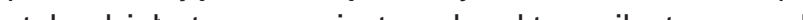

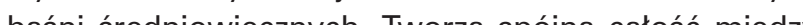

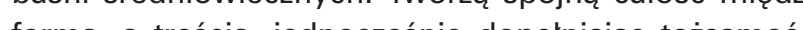
tożsamości historycznego miasta Hamleta.

PODSUMOWANIE

Autorka badając zróżnicowane przykłady zespołów murali w przestrzeni dochodzi do wniosku, że niezależnie

\begin{tabular}{|l|l|l|}
\hline \multicolumn{1}{|c|}{ Obszar } & \multicolumn{1}{c|}{ Dominująca cecha formalna } & \multicolumn{1}{c|}{ Dominująca funkcja } \\
\hline ZALIPIE & dekoratywność, elementy sztuki ludowej & $\begin{array}{l}\text { dekoracyjna, budowanie tożsamości } \\
\text { miejsca }\end{array}$ \\
\hline CHRISTIANIA & $\begin{array}{l}\text { chaotyczność, przemieszanie sztuki ulicy } \\
\text { o wysokich i niskich walorach estetycznych }\end{array}$ & $\begin{array}{l}\text { oznaczenie terytorium dzielnicy, prezen- } \\
\text { towanie tożsamości miejsca }\end{array}$ \\
\hline IRLANDIA PÓŁNOCNA & realizm, informatywność & dydaktyczna, polityczna \\
\hline TEHERAN & ujednolicenie form, symbolizm & $\begin{array}{l}\text { dydaktyczna, politycźna, } \\
\text { budowanie tożsamości narodowej }\end{array}$ \\
\hline ŁÓDŹ & $\begin{array}{l}\text { zróżnicowanie form, wysoka wartość } \\
\text { artystyczna }\end{array}$ & $\begin{array}{l}\text { estetyzujajca, maskująca mankamenty } \\
\text { struktury miejskiej }\end{array}$ \\
\hline HELSINGOR & stylizowanie, informatywna & $\begin{array}{l}\text { dydaktyczna, przywracanie tożsamości } \\
\text { miejsca }\end{array}$ \\
\hline
\end{tabular}

\begin{tabular}{|l|l|l|}
\hline \multicolumn{1}{|c|}{ Location } & \multicolumn{1}{|c|}{ Dominant formal characteristic } & \multicolumn{1}{c|}{ Dominant function } \\
\hline ZALIPIE & Decorativeness, elements of folk art & $\begin{array}{l}\text { Decorative, building the identity of the } \\
\text { place }\end{array}$ \\
\hline CHRISTIANIA & $\begin{array}{l}\text { Chaos, mixture of street art of high and low } \\
\text { aesthetic value }\end{array}$ & $\begin{array}{l}\text { Marking the territory of the district, } \\
\text { presenting the identity of the place }\end{array}$ \\
\hline NORTHERN IRELAND & Realism, informativeness & Didactic, political \\
\hline TEHRAN & Uniformity of forms, symbolism & Didactic, political, building national identity \\
\hline EÓDŹ & Variety of forms, high artistic value & $\begin{array}{l}\text { Aesthetisation, masking the defects of the } \\
\text { urban structure }\end{array}$ \\
\hline HELSINGOR & Stylisation, informative & Didactic, restoring the identity of the place \\
\hline
\end{tabular}

od skali opracowywanych dzieł, powtarzającą się funkcja, jaką pelnią jest budowanie i umacnianie tożsamosci miejsca, zatem ich charakterystyka mocno powiazzania jest uwarunkowaniami spolecznymi danej lokalizaci. Glownym jednak podziałem charakteryzujacym dane przypadki jest przeznaczenie murali - czy dominuje wsrod nich uzytecznosc czy estetyzacja danej przestrze-

Choć Teheran i Łódź są miastami trudnymi do porównania ze wzgledu różnorodność antropogeniczna to jednak okazały się być przykładami najbardziej prze ciwstawnymi, pod wzgledem analizy przeznaczenia murali. W obu przypadkach powstawanie licznych malowdet jest konsekwencia polityki mist. W Teheranie sa przede wsystkim użyteznym narzelzien do realiza

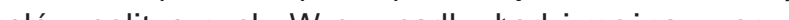

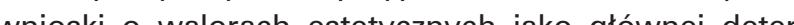
whina o walorach estetycznych jazo glownej deterdowie powstawania murall. Artyści w Lodzi maja dotego tez gany i obieranych przez siebie tematón, wym pryz ga ria Urban Forns wydaje się być modeloWym przykladem kontrolowanej sztuki ulicznej na wysowy pozyomie artystycznym, kóra jednocześnie wplywa na pozytywną percepcję przestrzeni publicznej.

Ważym jednak przypadku omawiane dzieła stanowia wartość dodaną do istniejącej już przestrzeni. Wykorzystując architekturę jak płotno stanowią inteligentne, współczesne ornamenty w przestrzeni, które, poza dekorowaniem, przekazują informacje i znaczenia, wchodząc w relację - i nieraz dialog - z mieszkańcami.

PRZYPISY

Loos A., Ornament izbrodnia. Eseje wybrane, Warszawa, Fundacja Centrum Architektury, 2013, s.136.

n. Cerkiew mastyru, Moldovi a Nowakowski A., Jak czytać architekturę, Kraków, Univiversitas, 2012, Cześ

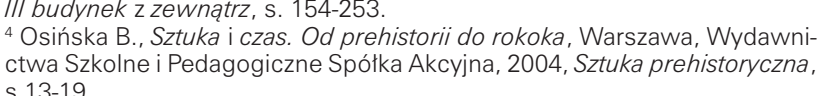
Street Street art- driatania artystyczne wykonane przestrzeni pozainstytucjonal
nej, najczessciej przestrzeni wielkomiejskiej, zachowujace walor masowe go odbiors i peennego stophila anonimowosci. Wiecej: Wasilewski J., Dro-

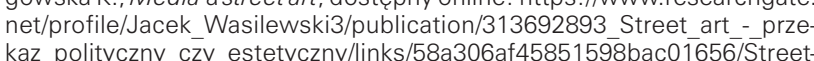
kaz-polityczny czy estettyczny/links/58a306at45851598bac0 $1656 /$ /Street

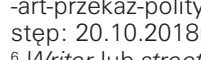

'Writer lub streetartworker - autor graftiti, sztuki uliczenej.

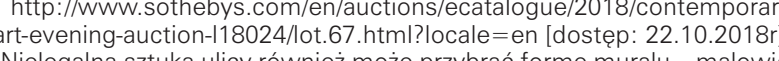
ta obejmuiacego ata sciane.

10
10 Mural liczy $5,728.62 \mathrm{~m}^{2} \mathrm{i}$ znajduie sie w Sao Paul guinnessworldrecords.com/world-records/1144466-largest-hpray-paint

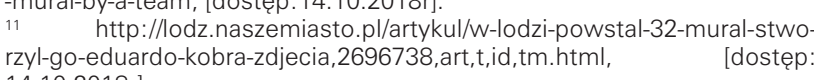
12 Byt wspóttwórca narodowego programu sztuki meksykańskiej, nawia-
zujaces do tradycii prekolumbijiskich i jednoczesnie sympatykiem idei komunistycznych, co nieraz przedstawiat w projektach swoich murali.
histros://en. wikipedia.org/wiki/Murals in Northern_lreland

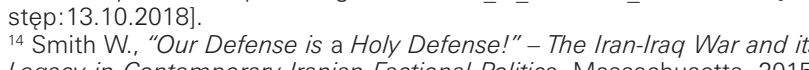

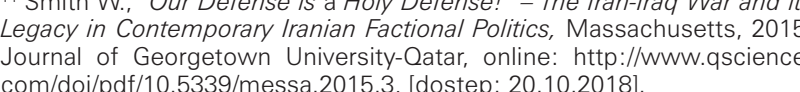

reinforcement of the identity of the place, which is why their characteristic is strongly tied with cial conditions of a given location. However, the main distinction that characterises individual cases is the purpose of the murals-whether they are dominated by utility or the aesthetisation of a given space.

ven through Tehran and Łódź are cities that are difficult to compare because of their anthropologica differences, they turned out to be the most mututhe pupose of muras in both cases the creation of numerous paintings is a consequence of municipa policy. In Tehran they are primarily a useful tool of achieving political goals. In the case of tódź we can formulate conclusions regarding aesthetic value as the primary determinant of the creation of murals. Artists in Łódź have freedom in terms of form and the subjects they can pursue, which is why the Urban Forms gallery appears to be a model example of controlled street art at a high artistic level, which also positively affects the perception of public space. However, in each of the cases that have been discussed, the works constiuted an added value to an already existing space. Using architecture as a canvas, they constitute smant, contemporary ornaments within space, which, apart from decorating, convey messages and meanings, entering into a relatio ship -and often into dialogue-with residents.

ENDNOTES

Loos A., Ornamenti zbrodnia. Eseje wybrane, Warszawa, Fund lacquers from synthetic resins became widespread at the start of

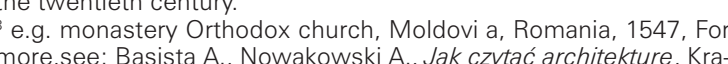
ków, Universitas, 2012, Cześć III budynek z zewnątrz, p. 154-253 OSińska B., Szztuka i czas. Od prehistorii do rokoka, Warszawa, Wy
dawnictwa Szkolne i i Pedagogiczne Spóktka Akcyina, 2004, Sztuka prehistoryczna, $p .13-19$.
5 Street art - artistic effor reception and a certain degree of anonymity. For more, see: Wa silewski J., Drogowska K., Media a street art, available online
https://www.researchgate.net/profilie/Jacek_Wasilewskij/publica

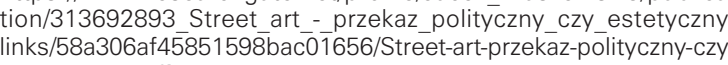
estetyczny.pdf? ?rigin=publication list. Iretrieved on: 20.10.2018 Writer or streetartworker - the author of graffitit or street art.
Banksy, Exit Through the Gift Shop, USA Great Britain, 2010 . hortp://Www.sothebys.com/en/auctions//ecatalogue/2018/contemporary-art-evening
on: 2.10 .2018$]$.
9 Illegal street art

政 10 The mural has a surface area of $5,728.62 \mathrm{~m}^{2}$ and is located in Sao Paulo. More at:http:///www.guinnessworldrecords.com/World
-records/1 1 14466-largest-spray-paint-mural-by-ateam, Iretrieved

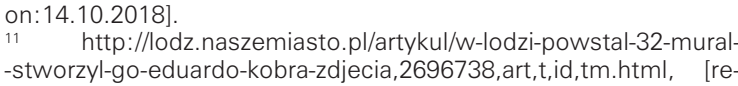
-stworzy-go-eduardo-ko
trieved on: 14.10 .2018$]$.
12 .

作 was the co-creator of the national programme of Mexican referring to pre-Columbian traditions and simultaneously a sym-
pathiser of communist ideology, which he often depicted in the ${ }_{3}$ hittps:///len. wikipadia. org/wiki/Murals_in_Northern_Ireland [retrie"Smith W., "Our Defense is a Holy Defensel" - The lran-lraq War and its Legacy in Contemporary ranian Factional Polliticis, Massa
chusetts, 2015, Journal of Georgetown University-Oatar, online chusetts, 2015, Journal of Georgetown University-Qatar, online
http://www. 9 science.com/doi/pdt/10.5339/messa.2015.3, Iretrie
ved on: 20.10 2018. 
15 http://fotini.mit.edu/sites/default/files/images/Chehabi Christia.pdf, [dostęp:18.10.2018].

16 Podobne zjawisko można zaobserwować także w innych miastach Iranu, ale w stolica charakteryzuje sie jego najwiękza intensywnościa

17 Więcej: https://www.km.com.pl/upload pdf/dzkie\%20murale.pdf [dostęp: 15.10.2018].

$18 \mathrm{http}: / /$ www.urbanforms.org/ [dostęp: 15.10.2018].

${ }^{19}$ W 2013 roku stacja CNN wyemitowała materiał dot. murali Urban Forms; HUFFINGTON POST w 2014 roku nadał Łodzi tytuł "The artsiest city", a ogólnoświatowy portal BOREDPANDA.com umieścił Łódź na drugim miejscu wśród 20 miast o najciekawszej sztuce w przestrzeni miejskiej.

http://lodz.naszemiasto.pl/artykul/powstala-mobilna-aplikacja-o-lodzkich-muralach,2728962,art,t,id,tm.html, [dostęp: 16.10.2018]

21 Więcej: Petelenz M., Zieleń łódzkich Bałut. Kompozycja przestrzenna miejsc pamieci, w: Housing Environment, nr22/2018, s.121-129.

22 Informacje i raport z badań: http://urbanforms.org/assets/Uploads/ Dialog-wokol-murali-raport.pdf, [dostęp: 16.10.2018].

${ }_{23}$ https://www.visitdenmark.nl/nl/denmark/murals-helsingor-middle-ages-and-sound-dues-gdk789176, [dostęp: 16.10.2018]

\section{BIBLIOGRAFIA}

[1] Basista Andrzej, Nowakowski Andrzej, Jak czytać architekturę, Kraków, Universitas, 2012, ISBN 97883-242-1767-0. Cześć III budynek z zewnatrz, s. 154-253.

[2] Biskupski Ł., Banksy: "Ta rewolucja to atrapa”, W: Kultura Popularna, nr $3(21) / 2008$, s. 85-97.

[3] Cullen Gordon, Obraz miasta. Wydanie skrócone, Lublin, Ośrodek Brama Grodzka, 2011, ISBN: 978-83-61064-22-0.

[4] Kodym-Kozaczko G., Detal "niezależny" - dopełnienie wspótczesnej przestrzeni architektonicznej, w: Czasopismo Techniczne. Architektura, 2012, R. 109, z. 5-A/2, s.285-290.

[5] Loos Adolf, Ornament i zbrodnia. Eseje wybrane, Warszawa, Fundacja Centrum Architektury, 2013, ISBN: 978-83-935538-9-1.

[6] Malinowska-Petelenz Beata, Ludwin Krzysztof, Brazylia.Potencjat, Kraków, Wydawnictwo PK, 2018, ISBN 978-83-7242-638-3.

[7] Niziołek K., Czy street art jest sztuką społeczną? Kulturotwórczy i obywatelski sens sztuki ulicznej w perspektywie koncepcji społecznych enklaw, w: Pogranicze. Studia Spoteczne, T. 26, 2015, s. 49-74.

[8] Osińska Barbara, Sztuka i czas. Od prehistorii do rokoka, Warszawa, Wydawnictwa Szkolne i Pedagogiczne Spółka Akcyjna, 2004, ISBN 978-83-02-09085-1. Sztuka prehistoryczna, s.13-19.

[9] Pallasmaa Juhani, Oczy skóry - Architektura i zmysty, Kraków, Instytut architektury, 2012, ISBN 978-83-63786-01-4.

[10] Petelenz M., Zieleń tódzkich Bałut. Kompozycja przestrzenna miejsc pamięci, w: Housing Environment, nr22/2018, s.121-129.

\section{ŹRÓDŁA INTERNETOWE:}

Wasilewski J., Drogowska K., Media a street art, Uniwersytet Warszawski, dosteppny online: https://www.researchgate.net/profile/ Jacek_Wasilewski3/publication/313692893_Street_art_-_przekaz_polityczny czy estetyczny/links/58a306af45851598bac016̄56/Street-art-przekaz-polityczny-czy-estetyczny.pdf?origin=publication list.][dostęp: 20.10.2018r].

Smith W., "Our Defense is a Holy Defense!" - The Iran-Iraq War and its Legacy in Contemporary Iranian Factional Politics, Massachusetts, 2015, Journal of Georgetown University-Qatar, online: http://www. qscience.com/doi/pdf/10.5339/messa.2015.3, [dostęp: 20.10.2018]. Marzolph Ulrich, The Martyr's Way to Paradise. Shiite Mural Art in the urban context, online: http://wwwuser.gwdg.de/ umarzol/ files/56Marzolph Martyrs.pdf, [dostep: 18.10.2018]

Chehabi H.E., Christia F., The art of state persuasion. Iran's post-revolutionary murals, online: http://fotini.mit.edu/sites/default/files/images/ Chehabi Christia.pdf, [dostęp: 18.10.2018].

https://Www.km.com.pl/upload_pdf/dzkie\%20murale.pdf [dostęp: 15.10.2018]

http://www.guinnessworldrecords.com/world-records/114466-largest-spray-paint-mural-by-a-team, [dostęp:14.10.2018r].

http://lodz.naszemiasto.pl/artykul/w-lodzi-powstal-32-mural-stworzyl-go-eduardo-kobra-zdjecia,2696738,art,t,id,tm.html, [dostęp: 14.10.2018r]

https://en.wikipedia.org/wiki/Murals in Northern Ireland [dostęp: 13.10.2018]

http://lodz.naszemiasto.pl/artykul/powstala-mobilna-aplikacja-o-lodzkich-muralach,2728962, art,t,id,tm.html, [dostep: 16.10.2018].

Informacje i raport z badań: http://urbanforms.org/assets/Uploads/ Dialog-wokol-murali-raport.pdf, [dostęp: 16.10.2018].

https://www.visitdenmark.nl/nl/denmark/murals-helsingor-middle-ages-and-sound-dues-gdk789176, [dostęp: 16.10.2018].
15 http://fotini.mit.edu/sites/default/files/images/Chehabi Christia.pdf [retrieved on:18.10.2018]

${ }^{16}$ A similar phenomenon can also be observed in other cities in Iran, but the capital is characterised by its highest intensity.

17 More at: https://www.km.com.pl/upload pdf/dzkie\%20murale.pdf [retrieved on: 15.10.2018]

$18 \mathrm{http}: / /$ www.urbanforms.org/ [retrieved on:15.10.2018].

${ }_{19}$ In 2013 the American news channel CNN aired a report on Urban Forms murals: HUFFINGTON POST in 2014 granted $Ł o$ dź the title of "The artsiest city", while the global website BOREDPANDA.com place Łódź second on its list of 20 cities with the most interesting art in urban space. 20 http://lodz.naszemiasto.pl/artykul/powstala-mobilna-aplikacja-o-lodzkich-muralach,2728962, art,t,id,tm.html, [retrieved on: 16.10.2018].

${ }^{21}$ For more, see: Petelenz M., Zieleń tódzkich Bałut. Kompozycja przestrzenna miejsc pamięci, in: Housing Environment, iss. 22/2018, p.121129

22 Information and research report: http://urbanforms.org/assets/Uploads/Dialog-wokol-murali-raport.pdf, [retrieved on: 16.10.2018].

${ }_{23} \mathrm{https}$ ://www.visitdenmark.nl/nl/denmark/murals-helsingor-middle-ages-and-sound-dues-gdk789176, [retrieved on: 16.10.2018].

\section{BIBLIOGRAPHY}

[1] Basista Andrzej, Nowakowski Andrzej, Jak czytać architekture, Kraków, Universitas, 2012, ISBN 97883-242-1767-0. Cześć II/ budynek z zewnatrz, p. 154-253.

[2] Biskupski Ł., Banksy: "Ta rewolucja to atrapa”, in: Kultura Popularna, iss. $3(21) / 2008$, p. 85-97.

[3] Cullen Gordon, Obraz miasta. Wydanie skrócone, Lublin, Ośrodek Brama Grodzka, 2011, ISBN: 978-83-61064-22-0.

[4] Kodym-Kozaczko G., Detal "niezależny" - dopełnienie wspótczesnej przestrzeni architektonicznej, in: Czasopismo Techniczne. Architektura, 2012, Y. 109, b. 5-A/2, p.285-290.

[5] Loos Adolf, Ornament i zbrodnia. Eseje wybrane, Warszawa, Fundacja Centrum Architektury, 2013, ISBN: 978-83-935538-9-1.

[6] Malinowska-Petelenz Beata, Ludwin Krzysztof, Brazylia.Potencjał, Kraków, Wydawnictwo PK, 2018, ISBN 978-83-7242-638-3.

[7] Niziołek K., Czy street art jest sztuką społeczną? Kulturotwórczy i obywatelski sens sztuki ulicznej w perspektywie koncepcji społecznych enklaw, in: Pogranicze. Studia Spoteczne, V. 26, 2015, p. 49-74.

[8] Osińska Barbara, Sztuka i czas. Od prehistorii do rokoka. Warszawa, Wydawnictwa Szkolne i Pedagogiczne Spółka Akcyjna, 2004, ISBN 97883-02-09085-1. Sztuka prehistoryczna, p.13-19.

[9] Pallasmaa Juhani, Oczy skóry - Architektura i zmysły, Kraków, Instytut architektury, 2012, ISBN 978-83-63786-01-4.

[10] Petelenz M., Zieleń łódzkich Bałut. Kompozycja przestrzenna miejsc pamiecci, in: Housing Environment, iss. 22/2018,p.121-129.

\section{ONLINE SOURCES :}

Wasilewski J., Drogowska K., Media a street art, Uniwersytet Warszawski, available online: https://www.researchgate.net/profile/ Jacek_Wasilewski3/publication/313692893_Street_art_-_przekaz_polityczny_czy_estetyczny/links/58a306af45851598bac01656/Street-art-przekaz-polityczny-czy-estetyczny.pdf?origin=publication list. [retrieved on: 20.10.2018]

Smith W., "Our Defense is a Holy Defense!" - The Iran-Iraq War and its Legacy in Contemporary Iranian Factional Politics, Massachusetts, 2015 Journal of Georgetown University-Qatar, online: http://www.qscience. com/doi/pdf/10.5339/messa.2015.3, [retrieved on: 20.10.2018]. Marzolph Ulrich, The Martyr's Way to Paradise. Shiite Mural Art in the urban context, online: http://wwwuser.gwdg.de/ umarzol/ files/56Marzolph Martyrs.pdf, [retrieved on: 18.10.2018].

Chehabi H.E., Christia F., The art of state persuasion. Iran's post-revolutionary murals, online: http://fotini.mit.edu/sites/default/files/images/ Chehabi Christia.pdf, [retrieved on: 18.10.2018]

https://www.km.com.pl/upload pdf/dzkie\%20murale.pdf [retrieved on: 15.10.2018]

http://www.guinnessworldrecords.com/world-records/114466-largest-spray-paint-mural-by-a-team, [retrieved on:14.10.2018]

http://lodz.naszemiasto.pl/artykul/w-lodzi-powstal-32-mural-stworzyl-go-eduardo-kobra-zdjecia,2696738,art,t,id,tm.html, [retrieved on: 14.10.2018].

https://en.wikipedia.org/wiki/Murals in Northern Ireland [retrieved on:13.10.2018]

http://lodz.naszemiasto.pl/artykul/powstala-mobilna-aplikacja-o-lodzkich-muralach,2728962, art,t,id,tm.html, [retrieved on: 16.10.2018]. Information and research report: http://urbanforms.org/assets/Uploads/Dialog-wokol-murali-raport.pdf, [retrieved on: 16.10.2018]. https://www.visitdenmark.nl/nl/denmark/murals-helsingor-middle-ages-and-sound-dues-gdk789176, [retrieved on: 16.10.2018]. 